\title{
ЦЕНТР-ПЕРИФЕРИЙНЫЕ РАЗЛИЧИЯ ПРОДОЛЖИТЕЛЬНОСТИ ЖИЗНИ В РОССИИ: РЕГИОНАЛЬНЫЙ АНАЛИЗ
}

\author{
АЛЕКСЕЙ ЩУР, СЕРГЕЙ ТИМОНИН
}

Высокий в сравнении со странами Запада уровень смертности и значительные пространственные различия в ожидаемой продолжительности жизни - серьезные вызовы, стоящие перед Россией. Решение задач повышения продолжстельности жизни и улучшения здоровья россиян, в том числе за счет уменьшения неравенства в смертности как между субъектами РФ, так и на внутрирегиональном уровне, тесным образом переплетаются с целями пространственного развития России, направленными на сокращение межрегиональных различий в уровне и качестве жизни людей.

В статье представлена оценка различий в смертности между «иентром» $и$ «периферией» регионов и динамика этих различий в 67 регионах России, в которых проживает три четверти населения страны. Период исследования - 2003-2018 г2. - характеризуется устойчивым ростом ожидаемой продолжительности жизни при рождении в России. Используя данные Росстата по городам, мьь оценили ожидаемую продолжительность жизни при рождении для 67 региональных центров и для остальной территории регионов («периферии»). В зависимости от величинь различий и динамики их изменений были вылелень 6 типов регионов (I-VI). Для регионов, в которых наблюдается наибольший иентр-периферийный разрыв в ожидаемой продолжительности жизни, применен метод декомпозиции, позволивший определить ключевые возрастные группь и причины смерти, ответственные за столь высокие различия.

В 36 регионах России, отнесенных к I-III типам, центр-периферийный разрыв превышал среднероссийский уровень, при этом лишь в 6 из них в 2003-2018 г2. отмечалась тенденция к сокращению разрыва. Анализ результатов декомпозиции различий в продолжительности жизни для первых трех типов регионов показал, что у мужчин отставание периферии от иентров обусловлено различиями 8 смертности в трудоспособном возрасте от внешних причин смерти, особенно от ДТП, убийств и самоубийств, а также от «алкогольных» причин смерти, у женщин - различиями в смертности в пожилом возрасте от хронических неинфекционных заболеваний.

Несмотря на, казалось бы, «объективный» характер центр-периферийных различий в уровне смертности в России (преимущество иентров в продолжительности жизни в первую очередь зависит от сочиально-демографических характеристик жителей, образовательной структуры населения, а также селективной миграции, направленной из периферии в ичентры), положительный опыт других стран показывает, что эффективная политика в области общественного здоровья может значительно сократить размах пространственного неравенства в уровне смертности даже при сохранении существенной гетерогенности в уровне социильно-экономического развития территорий.

Ключевые слова: ожидаемая продолжительность жизни, смертность, регионы России, региональные центры, иеетр и периферия.

АЛЕКСЕЙ ЕВГЕНЬЕВИч ЩУР (aschur@hse.ru), НАЦИОНАЛЬНЫЙ ИССЛЕДОВАТЕЛЬСКИЙ УНИВЕРСИТЕТ «ВЫСШАЯ ШКОЛА ЭКОНОМИКИ», РОсСия.

СЕРГЕЙ АНДРЕЕВИч ТИМОНИН (stimonin@hse.ru), НАЦИОНАЛЬНЫЙ ИССЛЕДОВАТЕЛЬСКИЙ УНИВЕРСИТЕТ «ВЫСШАЯ ШКОЛА ЭКОНОМикИ», РОссия.

СТАТЬЯ ПОДГОТОВЛЕНА В РЕЗУЛЬТАТЕ ПРОВЕДЕНИЯ ИССЛЕДОВАНИЯ В РАМКАХ ПРОГРАММЫ ФУНДАМЕНТАЛЬНЫХ ИССЛЕДОВАНИЙ НАЦИОНАЛЬНОГО ИССЛЕДОВАТЕЛЬСКОГО УНИВЕРСИТЕТА «ВЫСШАЯ ШКОЛА ЭКОНОМИКИ» (НИУ ВШЭ).

СТАТЬЯ ПОСТУПИЛА В РЕДАКЦИЮ В АВГУСТЕ 2020 Г. 


\section{ВВЕДЕНИЕ}

Административные центры регионов России разительно отличаются по уровню экономического и социального развития от окружающих их территорий, концентрируя значительную часть человеческого, институционального, финансового и политического капитала страны (Лексин 2009). Период после распада СССР характеризуется усилением поляризации пространства между «центром», на уровне всей страны представленным московским столичным регионом, а на уровне субъектов федерации - региональными столицами, и обширной «периферией», как внешней (слабо освоенные пространства Севера, Сибири и Дальнего Востока), так и «внутренней», определяемой в каждом регионе через ее положение по отношению к «центру» ${ }^{1}$ (Нефедова, Трейвиш 2020). Поляризация пространства затрагивает различные стороны жизни населения России. Одним из первостепенных, на наш взгляд, является вопрос пространственного неравенства россиян в уровне смертности. Неслучайно было отмечено, что именно дифференциация групп населения по уровню смертности очень точно характеризует уровень социальноэкономического неравенства в обществе (Sen 1998).

Изучение географических различий в смертности в России всегда было в фокусе внимания отечественных демографов, географов и социал-гигиенистов (Новосельский 1911; 1916). В 1970-е-1980-е годы на основе данных, собранных в околопереписной период, было показано, что величина ожидаемой продолжительности жизни снижается по мере движения по территории России с юга на север и с запада на восток (Андреев 1979; Школьников 1987). Самые низкие показатели смертности отмечались на Северном Кавказе, в Черноземной полосе и в отдельных регионах Поволжья, самые высокие - на Севере Европейской России, в Восточной Сибири и на Дальнем Востоке. Эта закономерность получила название «юго-западный/северо-восточный градиент смертности». При этом данный феномен оказался поразительно стабильным, несмотря на значительные колебания смертности в России с середины 1980-х до начала 2000-х годов (Vasin, Costello 1997).

Современный этап устойчивого роста ожидаемой продолжительности жизни, начало которого принято относить к 2003-2005 гг. (Вишневский, Щур 2019), охватил все регионы страны (Timonin et al. 2017; Захаров 2017) и поставил закономерный вопрос: сопровождается ли период роста продолжительности жизни сокращением межрегионального неравенства в уровне смертности? Отвечая на него, Тимонин и соавторы обнаружили, что межрегиональная дисперсия - одна из величин, позволяющих количественно оценивать пространственные различия в ожидаемой продолжительности жизни - остается практически неизменной с 2005 г. Однако разложение изменений этой меры неравенства по возрастам показывает, что субъекты РФ сближаются друг с другом по показателям смертности в детских и трудоспособных возрастах, а в старших возрастах, напротив, наблюдается картина дивергенции, в первую очередь из-за более быстрого снижения смертности пожилого населения в Москве и Санкт-Петербурге (Timonin et al. 2017).

\footnotetext{
1 Здесь и далее в тексте под «центрами» будут пониматься административные центры субъектов РФ, под «периферией» - остальная часть территории субъектов.
} 
Особое, привилегированное, положение Москвы и Санкт-Петербурга на «карте смертности» России впервые обозначилось в конце 1990-х годов и продолжало нарастать на протяжении 2000-х (Андреев, Кваша, Харькова 2006; Папанова, Школьников Тимонин 2019). Вероятно, не последнюю роль в этом сыграла усилившаяся с начала 2000-х годов политическая и экономическая роль Москвы и, в меньшей степени, Санкт-Петербурга. К ее последствиям среди прочего можно отнести и значительный миграционный приток в эти центры и их регионы, сверхконцентрацию в них человеческого капитала, более высокий уровень жизни, в том числе и более высокие расходы на здравоохранение - все эти факторы напрямую влияют на величину ожидаемой продолжительности жизни (Marmot 2005). Вместе с тем, из-за ограниченности данных, изучение географического неравенства в смертности в России до самого последнего времени затрагивало лишь самый верхний уровень административно-территориального деления. Как следствие, значительная часть центр-периферийных различий в уровне смертности оставалась «скрытой» от исследователей (Timonin et al. 2020).

Наличие доступа к данным о распределении умерших по полу, возрасту и причинам смерти в региональных центрах, помимо Москвы и Санкт-Петербурга, дало нам возможность оценить величину ожидаемой продолжительности жизни при рождении для подавляющего числа российских областных, краевых и республиканских столиц, а также рассчитать некоторые другие показатели, характеризующие эпидемиологические модели смертности в них.

Цель исследования - оценить тенденции в изменении ожидаемой продолжительности жизни населения региональных центров и остальных частей субъектов РФ (периферии) в условиях общероссийского снижения уровня смертности, наблюдающегося с 2004 г. Насколько велико преимущество региональных столиц в продолжительности жизни над «своими регионами»? Как оно менялось последние 15 лет? Как регионы отличаются по величине и направлению изменений центр-периферийного неравенства в уровне смертности? Смертность в каких возрастных группах и от каких причин смерти вносит наибольший вклад в дифференциацию ожидаемой продолжительности жизни между региональными центрами и остальной территорией субъектов? В данном исследовании мы постарались ответить на эти и некоторые другие вопросы.

\section{ДАННЫЕ И МЕТОДЫ}

Федеральная служба государственной статистики России (Росстат) не публикует оценки ожидаемой продолжительности жизни для российских городов, кроме Москвы, Санкт-Петербурга и - с 2015 г. - Севастополя. Однако Росстат разрабатывает таблицы с распределением умерших по полу, возрасту и причинам смерти для всех российских городов с численностью постоянного населения свыше 100 тыс. человек, а также оценивает среднегодовую численность их населения по полу и однолетним возрастным группам. На основе этих данных были построены краткие (до возраста 85+) таблицы смертности отдельно для мужчин и женщин и получены оценки ожидаемой продолжительности жизни при рождении (e) за 2003-2018 гг. для 67 российских городов - региональных столиц. 
Из нашего исследования, кроме Москвы, Санкт-Петербурга, Московской и Ленинградской областей, а также Республики Крым и Севастополя, были исключены регионы, чьими столицами в 2003 г. были города с численностью населения менее 100 тыс. человек (Чукотский и Ямало-Ненецкий АО, Магаданская область, Еврейская АО, Республика Алтай) ${ }^{2}$. Кроме того, были исключены 6 республик Северо-Кавказского федерального округа, в отношении которых имеются обоснованные опасения, касающиеся качества демографических данных, в первую очередь оценок численности постоянного населения и полноты регистрации смертей (Андреев 2012; Мкртчян 2012). Тем не менее в охваченных исследованием регионах в 2018 г. проживало почти 110 млн человек или около $3 / 4$ всего населения страны.

Данные о числах и возрасте умерших, а также о среднегодовой численности населении для 67 регионов, чьими центрами являются отобранные города, были взяты из Российской базы данных рождаемости и смертности РЭШ (РосБРиС) (Российская экономическая школа 2019). Путем вычитания одного набора данных (по городам) из другого (по регионам) были получены соответствующие оценки чисел умерших для 67 регионов без их центров; для новых единиц - регионов без центров (периферии) мы также рассчитали величину $e_{0}$.

В зависимости от средней за 2011-2018 гг. величины разрыва в $e_{0}$ между региональным центром и остальной частью субъекта все регионы были разделены на два типа: регионы, в которых отрыв центров был выше среднего для всех регионов (I-III типы), и те, в которых он был ниже (IV-VI типы). Далее мы проанализировали динамику разрыва за 2003-2018 гг. В соответствии с ней каждый регион был отнесен к одному из трех типов: регионы, где наблюдалась тенденция к усилению преимущества центра (т. е. происходила дивергенция в $e_{0}$ между центром и остальной частью региона); регионы, где разрыв оставался примерно на одном уровне (не наблюдалось статистически значимой (выраженной) тенденции) и регионы, где разрыв снижался (т. е. происходила конвергенция). Таким образом, сочетание этих двух характеристик позволило нам выделить 6 типов регионов (таблица Приложения).

К первым трем типам регионов (с разрывом выше среднего по всей выборке) мы применили метод декомпозиции (Андреев 1982) в одной временной точке (в 2018 г.) для выявления, какие возрастные группы и причины смерти определяют преимущество центров в ожидаемой продолжительности жизни при рождении перед периферией. Для первых трех типов регионов также были рассчитаны стандартизованные коэффициенты смертности по европейскому стандарту населения 1976 г. для основных классов и групп причин смерти отдельно в региональных центрах и за их пределами.

\footnotetext{
${ }^{2}$ Исключения - ХМАО (где «центром» был выбран г. Сургут, а не формальная столица г. Ханты-Мансийск) и НАО, в данном исследовании рассматриваемый вместе с Архангельской областью. 


\section{О СОПОСТАВИМОСТИ ВО ВРЕМЕНИ ОЦЕНОК ЧИСЛЕННОСТИ НАСЕЛЕНИЯ ВНУТРИ РЕГИОНОВ}

Существует два главных источника информации о численности и половозрастной структуре населения в России: переписи населения, являющиеся основным источником данных, и текущий учет демографических событий (рождений, смертей, смены постоянного места жительства, т. е. миграций) для оценок численности и состава населения в межпериписной период. Завышение численности населения на одних территориях и ее недоучет в других в межпереписной период происходит в основном за счет миграционной компоненты (постановки на учет прибывших и снятия с него выбывших). Завышение или занижение официальной численности населения, в том числе и в отдельных возрастах влечет за собой искажение величины ожидаемой продолжительности жизни вследствие недостоверности знаменателя, используемого при расчете возрастных коэффициентов смертности.

Доля населения, проживающего в центрах регионов, во всем населении увеличивалась на протяжении всего исследуемого периода (рисунок П1 Приложения). Сильно выделяется резкой скачок в доле населения между 2010 и 2011 г., что связано с традиционной корректировкой численности населения, выполненной по итогам Всероссийской переписи населения 2010 г. Это означает, что фактическая численность населения в большинстве региональных центров оказалась выше расчетной (главным образом из-за недоучтенной миграции), в то время как в прочих населенных пунктах, наоборот, расчетная численность населения была завышена (Росстат 2012). Поскольку предыдущая перепись населения в России проходила в 2002 г., накануне рассматриваемого нами периода, то с каждым последующим годом накопленная ошибка в оценке численности населения только возрастала, достигнув максимума в 2010 г.

Путем ретроспективной экстраполяции линейного тренда роста доли центров в 20112018 гг. нами были получены скорректированные на результаты переписи 2010 г. оценки численности населения в центрах и на остальной территории регионов за 2003-2010 гг. ${ }^{3}$ Ниже будет показано, какое влияние недоучет численности населения в центрах и, соответственно, переучет в остальной части регионов оказал на величину и динамику разрыва в е между ними.

\section{ТИПОЛОГИЯ РЕГИОНОВ РОССИИ В ЗАВИСИМОСТИ ОТ РАЗМАХА И ДИНАМИКИ ЦЕНТР-ПЕРИФЕРИЙНОГО РАЗРЫВА В ПРОДОЛЖИТЕЛЬНОСТИ ЖИЗНИ}

В 2003-2018 гг. ожидаемая продолжительность жизни при рождении в региональных центрах превышала соответствующий показатель в остальных населенных пунктах на 1,82,8 года в зависимости от календарного года (рисунок 1). Самые быстрые темпы роста разрыва в ео между центром и периферией были отмечены в 2004-2005 гг., когда он

\footnotetext{
${ }^{3}$ Официально Росстат делает ретроспективный пересчет численности населения только для субъектов РФ. 
увеличился на 0,7 года. Именно в этот период, как показали Тимонин и соавторы (Timonin et al. 2017), уровень межрегионального неравенства в уровне смертности в России был максимален с 1970-х годов. Можно предположить, что региональные центры оказались в авангарде снижения уровня смертности в России в 2000-х годах, поскольку переход к устойчивому росту $e_{0}$ в них обозначился с 2003 г., когда как в остальных населенных пунктах это произошло не ранее 2006 г.

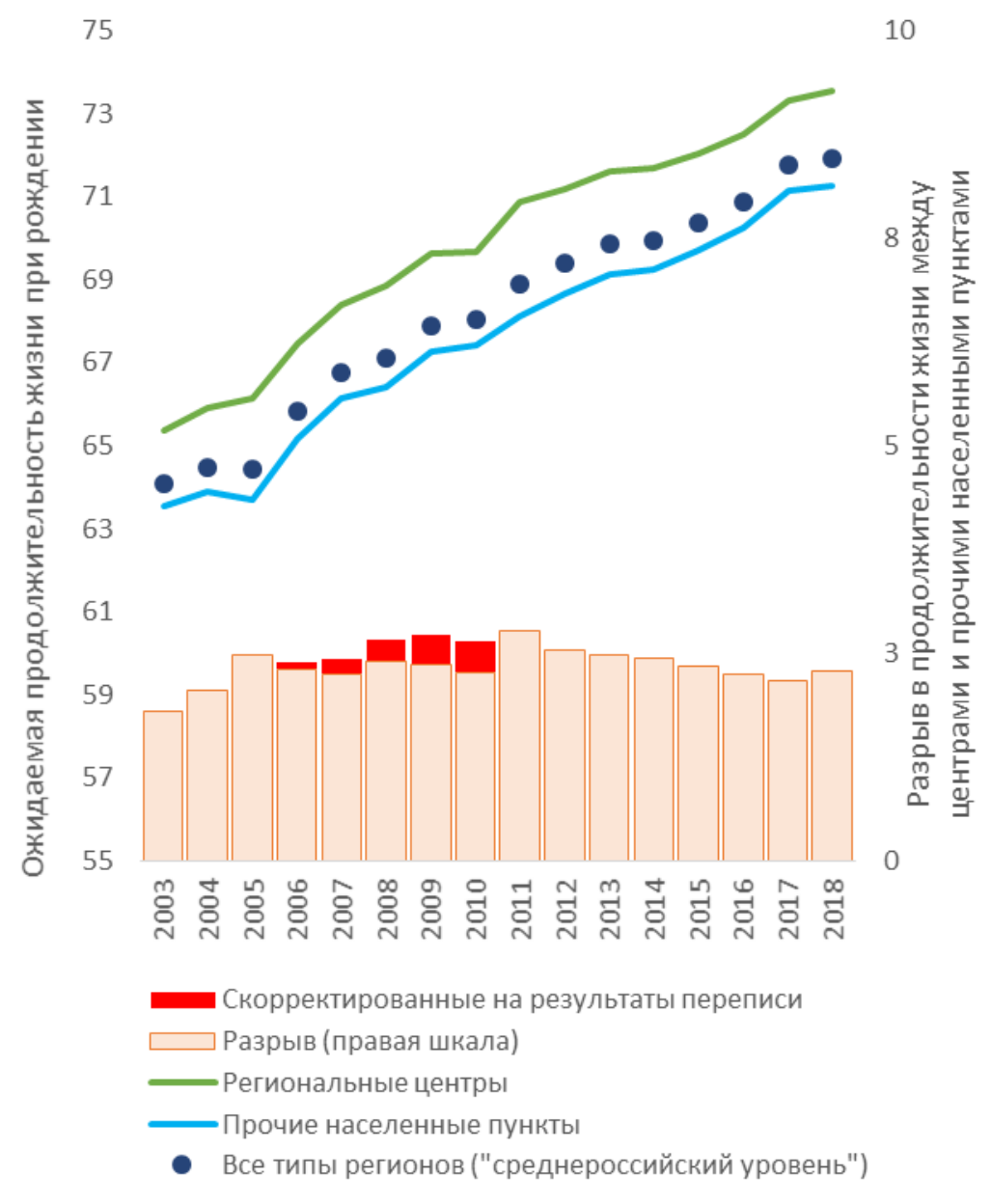

\section{Рисунок 1. Ожидаемая продолжительность жизни (ео) при рождении в региональных центрах и прочих населенных пунктах регионов (левая шкала) и соответствующий разрыв в $e_{0}$ между ними (правая шкала), лет, 2003-2018}

В 2007-2010 гг. разрыв оставался примерно на одном уровне по нескорректированным на результаты переписи данным и продолжал увеличиваться вплоть до 2011 г., если ориентироваться на скорректированные данные. Разница между двумя вариантами расчета достигала 0,4 года (для 2010 г.). После 2011 г. ожидаемая продолжительность жизни за пределами региональных центров стала расти опережающими темпами, в результате чего наметилась тенденция к конвергенции (разрыв в $e_{0}$ сократился с 2,8 года в 2011 г. до 2,2 в 2017 г.), которая, впрочем, прервалась в 2018 г. Таким образом, рассматриваемый период можно разделить на два этапа: первый - увеличение преимущества центров в ожидаемой продолжительности жизни в 2003-2011 гг., за которым последовал второй этап - сокращение различий в $e_{0}$ между ними и остальными населенными пунктами. 


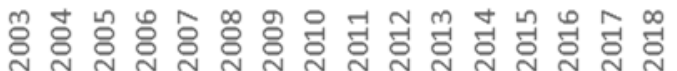

II. Высокий разрыв, нет тенденции

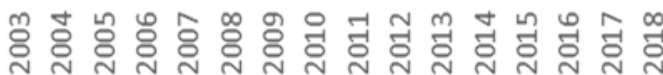

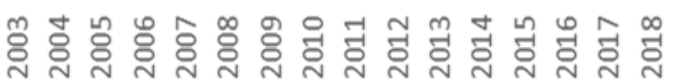

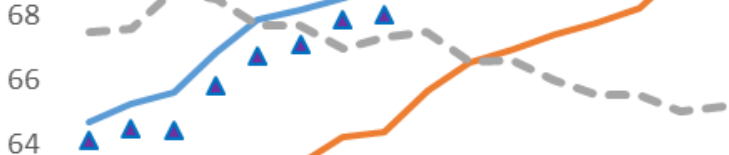

62

60

Ццентр

- Разрыв (правая шкала)

\section{Рисунок 2. Ожидаемая продолжительность жизни при рождении в центрах и на} периферии и величина размаха между ними (правая шкала) по типам регионов, лет, 
Однако анализ по отдельным регионам показал значительную степень гетерогенности в уровне и динамике изменений разрыва в ожидаемой продолжительности жизни между центрами и периферией. Исходя из этих двух параметров (величина разрыва и его динамика), нами были выделены 6 типов регионов (состав каждого выделенного типа представлен в таблице Приложения). В 22 регионах отрыв центра от остальной территории региона в 2003-2018 гг. существенно увеличился, хотя и с разного начального уровня, в 17 регионах разрыв, наоборот, сократился, тогда как в оставшихся 28 регионах четко выраженной тенденции выявлено не было.

На рисунке 2 для каждого типа регионов (I-VI) приведены значения ео в центрах, на периферии и разрыв между ними, также на всех графиках присутствует кривая ожидаемой продолжительности жизни для России в целом («все типы регионов») 4 .

Как видно из рисунка 2, рост продолжительности жизни в 2003-2018 гг. имел место во всех типах регионах - как в их центрах, так и на периферии. В I и IV типах регионов (высокий и низкий разрыв; дивергенция) темпы роста $e_{0}$ в центрах опережали таковые на периферии. К первому типу с существенным и растущим центр-периферийным разрывом относятся Байкальский макрорегион (Иркутская область, Республика Бурятия и Забайкальский край), а также Республики Тува и Якутия, образующие единый мегакластер на востоке страны; Сахалинская область на Дальнем Востоке, а также регионы вдоль Транссибирской магистрали - Свердловская, Тюменская (без округов), Омская, Новосибирская области. На западе страны данный тип представлен Архангельской, Курской, Ростовской областями, Республиками Коми и Марий Эл (рисунок 3). Величина ожидаемой продолжительности жизни в данном типе регионов ниже среднероссийской, в первую очередь за счет высокого уровня смертности на периферии 5 .

B IV типе регионов, напротив, наблюдаются самые высокие значения ожидаемой продолжительности жизни (рисунок 4). К данному типу принадлежат Белгородская, Воронежская, Волгоградская, Астраханская и Мурманская области, Республики Татарстан и Башкирия. Для всех этих регионов, кроме Мурманской области, характерен низкий уровень смертности в центрах при относительно благоприятном, в целом, положении дел на периферии. Тем не менее в них четко прослеживается тенденция нарастания отставания периферии от центров по величине ожидаемой продолжительности жизни.

Регионы II типа со значительным центр-периферийным разрывом, но без статистически значимой тенденции к дивергенции/конвергенции географически «дополняют» регионы I типа, сосредоточившись на Дальнем Востоке (Приморский, Хабаровский край, Амурская область), в Сибири (Красноярский край, Республика Хакассия, Кемеровская и Томская области), в Уральском (Республика Удмуртия, Курганская, Оренбургская и Челябинская области) и Волго-Вятском (Чувашия, Кировская

\footnotetext{
4 Здесь и далее речь идет о России в составе 67 исследуемых регионов (без столичных регионов и республик Северного Кавказа).

${ }^{5}$ Исключение - Ростовская область, высокий уровень центр-периферийного разрыва в которой - следствие, в первую очередь, низкого уровня смертности в Ростове-на-Дону (одного из самых низких среди региональных столиц), при в целом посредственном, но далеко не самом худшем положении дел на периферии.
} 
область - в восточной его части) экономических районах, на севере Европейской России Республика Карелия; в центре страны - Владимирская область. Как и для первого, для второго типа характерен высокий уровень смертности на периферии, а кривые $e_{0}$ для двух типов на графике (рисунок 4) практически идентичны и лежат ниже среднероссийского уровня. Главное отличие между двумя типами - более медленные темпы роста $e_{0}$ в центрах регионов II типа по сравнению с I, что и предопределило разницу между ними в траектории центр-периферийного разрыва.

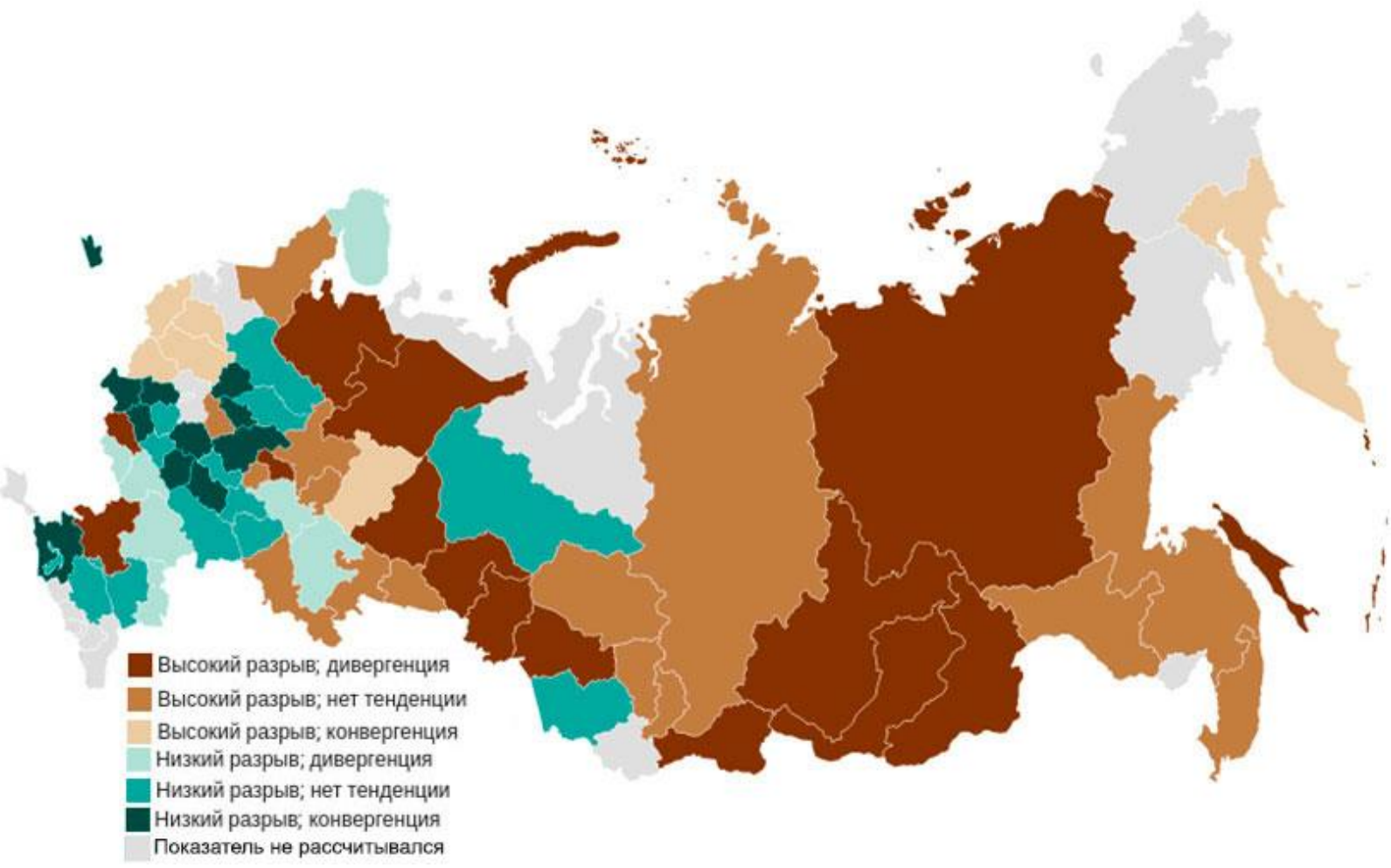

Рисунок 3. Типы регионов в зависимости от величины разрыва в ожидаемой продолжительности жизни между региональной столицей и остальными населенными пунктами и динамики разрыва, в среднем, 2003-2018

Самый малочисленный как по составу (6 субъектов), так и по численности населения (6,4 млн человек) тип - третий. Его образует компактный кластер на северо-западе европейской части страны (Псковская, Новгородская, Тверская, Смоленская области), также к нему отнесены Пермский и Камчатский края. Для данного типа характерны самые низкие значения $e_{0}$ как в центре, так и на периферии. Тем не менее, показав существенное сокращение центр-периферийного разрыва в ожидаемой продолжительности жизни, III тип также продемонстрировал и самые высокие темпы снижения уровня смертности в 20032018 гг. среди всех типов регионов (рисунок 4). Так, если в 2003 г. его отставание от I типа регионов и от России в целом составляло 1,3 и 2,4 года, то в 2018 г. оно сократилось до 0,2 и 1,3 года соответственно.

Пятый (низкий разрыв; нет тенденции) и шестой (низкий разрыв; конвергенция) типы представлены по большей части регионами, относящимися к Центральной России Черноземью, Центральному, Северо-Кавказскому и Поволжскому экономическим районам, западу Волго-Вятского района (Нижегородская область, Мордовия). Из азиатской части 
страны в нем представлены лишь два субъекта: Алтайский край и ХМАО. Начиная с 2010 г., кривые $e_{0}$ для двух этих типов сливаются и лежат выше среднероссийских значений, при этом темпы роста $e_{0}$ в VI типе, для которого характерна конвергенция, в 2003-2018 гг. были выше, чем в V, и уступали только III типу, в котором в обозначенный период также наблюдалась центр-периферийная конвергенция, но с более высокого первоначального уровня центр-периферийного неравенства.

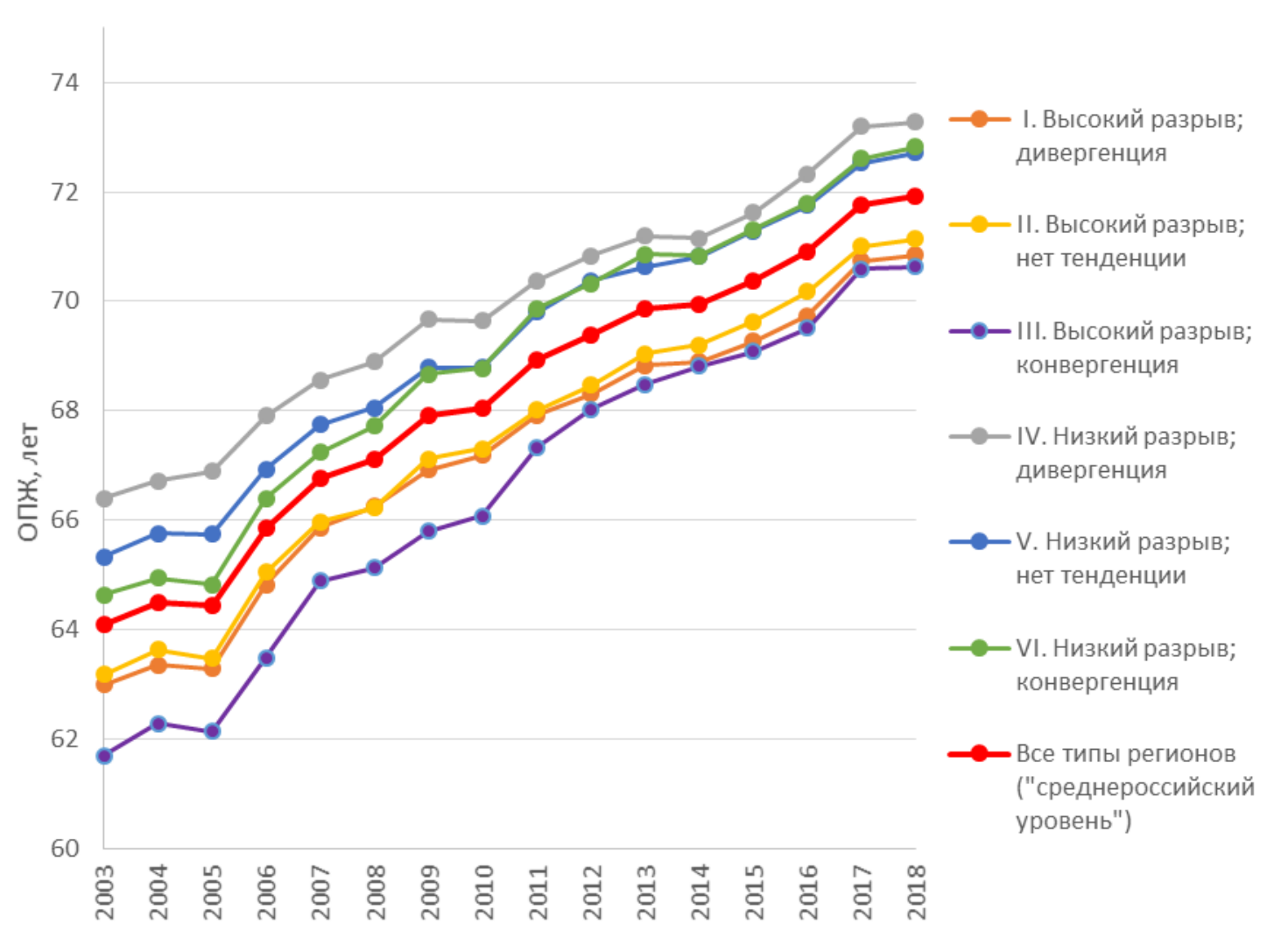

\section{Рисунок 4. Ожидаемая продолжительность жизни при рождении в зависимости от типа регионов, лет, 2003-2018}

Неравенство в уровне смертности между типами регионов, выраженное через величину стандартного отклонения, уменьшалось в 2006-2014 гг., но в последние годы конвергенция практически остановилась. Расстояние между тремя верхними кривыми на графике (рисунок 4), объединяющими регионы с низким разрывом в $e_{0}$, и тремя нижними кривыми, отражающими регионы, где он, напротив, высокий, с 2015 г. составляет примерно 2 года. Это в свою очередь эквивалентно суммарному приросту $e_{0}$ в России за 5 календарных лет ${ }^{6}$. При этом размах неравенства в $e_{0}$ на периферии между всеми шестью типами регионов существенно выше, чем между их центрами: в 2018 г. - 3,2 и 1,9 года соответственно. Подобная ситуация ожидаема, учитывая, что столицы регионов - более гомогенная группа объектов, включающая в себя только города с населением свыше 100 тыс. человек, тогда как «периферия», как минимум с точки зрения структуры расселения, сильно дифференцирована в зависимости от конкретного региона.

\footnotetext{
6 Усредненный среднегодовой прирост $e_{0}$ в России на современном этапе снижения смертности колеблется на уровне 0,4-0,5 года (в зависимости от года начала этапа).
} 
Таким образом, межрегиональное неравенство в смертности в России, в том числе ее «югозападный/северо-восточный градиент», определяется, большей частью, неравенством в смертности на «периферии» российских регионов, а не в их центрах.

Итак, значение разрыва в $e_{0}$ между центром и остальной частью региона определяется практически полностью уровнем смертности на периферии, в то время как направление изменения разрыва зависит от динамики $e_{0}$ как в центре, так и на периферии. В регионах, где разрыв в $e_{0}$ уменьшается, это происходит в первую очередь за счет догоняющих темпов снижения уровня смертности за пределами центра. Напротив, регионы, для которых характерна дивергенция в уровне смертности между центром и периферий, отличаются более высокими значениями и темпами роста $e_{0}$ в столицах. Кроме того, в IV-VI типах регионов, где центр-периферийный разрыв ниже, чем в среднем по стране, значения $e_{0}$ выше и, наоборот, в I-III типах значения $e_{0}$ ниже среднероссийского, а разрыв - выше. При этом самый быстрый рост ожидаемой продолжительности жизни в 2003-2018 гг. на уровне всего региона (без разделения на центр и периферию) показали III и VI типы, где отмечалась конвергенция в показателях смертности между центром и периферией.

\section{РЕГИОНЫ РОССИИ С ВЫСОКИМ УРОВНЕМ ЦЕНТР-ПЕРИФЕРИЙНЫХ РАЗЛИЧИЙ В ОЖИДАЕМОЙ ПРОДОЛЖИТЕЛЬНОСТИ ЖИЗНИ: РОЛЬ ВОЗРАСТА И ПРИЧИН СМЕРТИ}

Сокращение отставания периферии регионов от их центров по уровню продолжительности жизни отвечает интересам гармоничного пространственного развития страны и должно быть одним из основных приоритетов системы общественного здравоохранения: всем жителям России вне зависимости от места их проживания гарантировано «право на здоровье».

Особенно остро проблема центр-периферийного неравенства в уровне смертности в России стоит в первых трех типах регионов (таблица Приложения); из 36 субъектов РФ, где разрыв в ео между центром и остальной частью региона превышал среднероссийский уровень, лишь в 6 в 2003-2018 гг. наблюдалась тенденция к его сокращению. В 2018 г. ожидаемая продолжительность жизни при рождении мужчин в центрах этих регионов была на 3,3 года выше, чем в остальных населенных пунктах, женщин - на 2,7 года выше (рисунок 5). Разложение центр-периферийного разрыва в смертности по возрастным группам и причинам смерти поможет выявить ключевые «проблемные точки», ответственные за отставание периферии в уровне ожидаемой продолжительности жизни.

Как показано на рисунке 5, отставание мужчин в $e_{0}$ на периферии - следствие их более высокой смертности от внешних причин смерти в младшем (15-39 лет) и среднем (4054 года) трудоспособном возрасте, а также, в меньшей степени, следствие более высокого уровня смертности от болезней системы кровообращения (БСК), в первую очередь от ишемической болезни сердца, и прочих БСК в среднем (40-64 года) и пожилом (65 и старше лет) возрасте. 


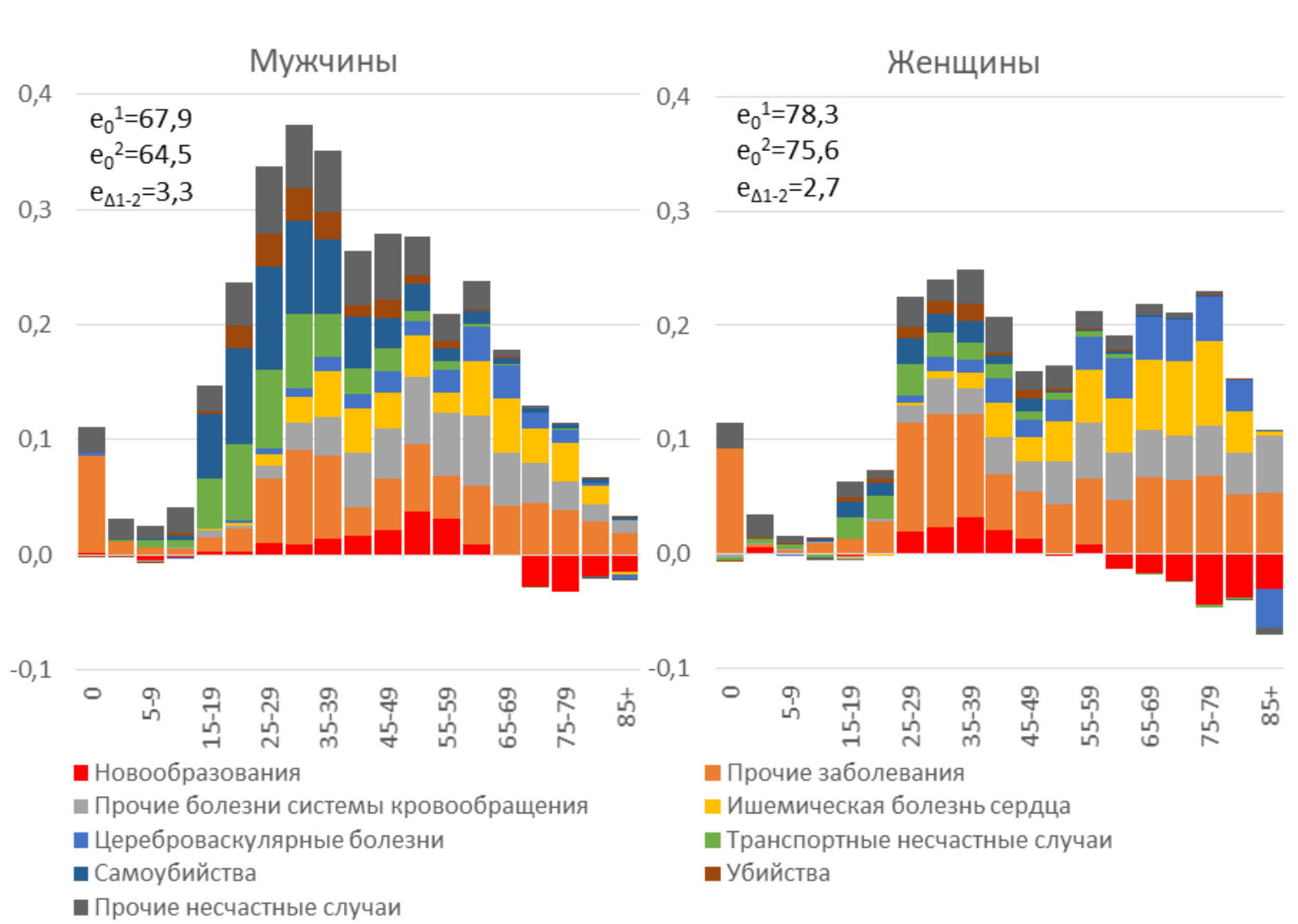

\section{Рисунок 5. Вклад возрастных групп и причин смерти в различия в ожидаемой продолжительности жизни при рождении между региональными центрами( $\left.{ }^{1}\right)$ и периферией $\left({ }^{2}\right)$ для мужчин и женщин, 2018}

Фактор более низкого уровня смертности от болезней системы кровообращения в среднем и пожилом возрасте в региональных центрах объясняет около половины их преимущества перед прочими населенными пунктами в ожидаемой продолжительности жизни женщин. Как и мужское, женское население за пределами региональных столиц характеризуется более выраженным «бугром сверхсмертности» от внешних причин смерти и прочих заболеваний (инфекций, болезней органов дыхания, пищеварения) в относительно молодом возрасте (25-44 года). «Омоложение» смертности от таких причин смерти, как туберкулез, ВИЧ-инфекция, пневмония, цирроз (в том числе алкогольный), кардиомиопатия (в том числе алкогольной этиологии), по мнению Ивановой и соавторов, может говорить о «маргинализации общества, снижении “качества” населения, расширении слоя лиц, слабо социально адаптированного и дезадаптированного» (Иванова, Михайлов, Семенова 2009: 41).

Примечательно, что регистрируемая смертность от новообразований в центрах регионов ниже, чем на остальной их территории в молодом и среднем возрастах, но выше в пожилом возрасте, причем, чем старше возрастная группа, тем выше разрыв по смертности не в пользу центров. По нашему мнению, что совпадает с позицией наших коллег (Данилова 2015; Папанова, Школьников, Тимонин 2019), этот факт не только не означает более благополучного положения с уровнем онкологической смертности на периферии, но и, наоборот, может свидетельствовать о недостаточной как прижизненной, 
так и посмертной диагностике онкологических заболеваний у пожилого населения вдали от больших городов.

В таблице показано соотношение стандартизованных коэффициентов смертности (CKC) в центре и на периферии от отдельных классов и причин смерти для 36 регионов, отличающихся значительным центр-периферийным разрывом в $e_{0}$. Женщины, проживающие в региональных центрах, как население с самым низким уровнем смертности были выбраны в качестве «референтной группы».

Таблица. Соотношения стандартизованных коэффициентов смертности, 2018

\begin{tabular}{|c|c|c|c|c|}
\hline Причина смерти & $\begin{array}{c}\text { Женщины } \\
\text { периферии к } \\
\text { женщинам } \\
\text { центра } \\
\end{array}$ & $\begin{array}{c}\text { Мужчины } \\
\text { центра к } \\
\text { женщинам } \\
\text { центра } \\
\end{array}$ & $\begin{array}{c}\text { Мужчины } \\
\text { периферии к } \\
\text { женщинам } \\
\text { центра } \\
\end{array}$ & $\begin{array}{c}\text { Мужчины } \\
\text { периферии к } \\
\text { мужчинам } \\
\text { центра } \\
\end{array}$ \\
\hline $\begin{array}{l}\text { Некоторые инфекционные и } \\
\text { паразитарные болезни }\end{array}$ & 1,24 & 2,61 & 2,73 & 1,05 \\
\hline $\begin{array}{l}\text { Злокачественные } \\
\text { новообразования (ЗНО) }\end{array}$ & 0,93 & 2,01 & 1,93 & 0,96 \\
\hline ЗНО органов пищеварения & 0,91 & 2,14 & 1,92 & 0,89 \\
\hline ЗНО органов дыхания & 1,01 & 6,81 & 7,82 & 1,15 \\
\hline $\begin{array}{l}\text { ЗНО половых и } \\
\text { мочевыводящих органов }\end{array}$ & 1,06 & 1,74 & 1,52 & 0,88 \\
\hline Прочие ЗНО & 0,86 & 1,06 & 0,95 & 0,89 \\
\hline Болезни нервной системы & 1,18 & 1,40 & 1,72 & 1,23 \\
\hline $\begin{array}{l}\text { Болезни системы } \\
\text { кровообращения (БСК) }\end{array}$ & 1,10 & 1,94 & 2,16 & 1,11 \\
\hline $\begin{array}{l}\text { Ишемическая болезнь } \\
\text { сердца }\end{array}$ & 1,04 & 2,10 & 2,20 & 1,05 \\
\hline $\begin{array}{l}\text { Цереброваскулярные } \\
\text { болезни }\end{array}$ & 1,02 & 1,60 & 1,67 & 1,04 \\
\hline Прочие БСК & 1,54 & 2,18 & 3,24 & 1,48 \\
\hline Болезни органов дыхания & 1,21 & 3,74 & 4,75 & 1,27 \\
\hline $\begin{array}{l}\text { Болезни органов } \\
\text { пищеварения }\end{array}$ & 1,23 & 1,87 & 2,19 & 1,17 \\
\hline Старость & 4,24 & 0,91 & 4,35 & 4,81 \\
\hline Неустановленные причины & 1,05 & 3,74 & 3,63 & 0,97 \\
\hline Внешние причины & 1,52 & 4,17 & 6,19 & 1,49 \\
\hline $\begin{array}{l}\text { Транспортные несчастные } \\
\text { случаи }\end{array}$ & 1,92 & 2,94 & 6,14 & 2,09 \\
\hline Самоубийство & 2,09 & 5,59 & 12,42 & 2,22 \\
\hline Убийство & 1,91 & 3,60 & 6,63 & 1,84 \\
\hline $\begin{array}{l}\text { Повреждения с } \\
\text { неопределенными } \\
\text { намерениями }\end{array}$ & 1,06 & 4,17 & 4,44 & 1,06 \\
\hline $\begin{array}{l}\text { Прочие несчастные } \\
\text { случаи }\end{array}$ & 1,69 & 4,32 & 6,52 & 1,51 \\
\hline Прочие заболевания & 1,26 & 1,26 & 1,35 & 1,07 \\
\hline Все причины смерти & 1,19 & 2,07 & 2,41 & 1,17 \\
\hline
\end{tabular}

Наиболее велики разрывы в СКС от внешних причин смерти: уровень смертности от них на периферии в 2018 г. был в 1,5 раза выше, чем в центрах, как у мужчин, так и у женщин. Уровень смертности от транспортных несчастных случаев у мужчин был в 2,1 раза выше за пределами региональных центров, от убийств - на $84 \%$ выше и от самоубийств в 2,2 раза выше, чем в столицах регионов, а уровень смертности от самоубийств мужчин на периферии почти в 12,5 раз превышал соответствующий показатель для женщин в центрах. 
Выделяются также «прочие болезни системы кровообращения (БСК)», СКС от которых за пределами региональных центров выше, чем в центрах, на 48 и 54\% для мужчин и женщин соответственно. За различиями в смертности от прочих БСК, в первую очередь, стоят различия в смертности от кардиомиопатии, явной и неявной алкогольной этиологии (Иванова, Семенова, Дубровина 2004). Кроме того, за пределами региональных столиц в 4-5 раз выше, чем в центрах, уровень смертности от «старости», которую принято относить к так называемым «мусорным причинам смерти», когда настоящая причина смерти так и не была установлена (Иванова и др. 2013). Злоупотребление «старостью» как причиной смерти также косвенно свидетельствует о низком качестве прижизненной и посмертной диагностики заболеваний у населения пожилого возраста (старше 80 лет).

\section{ЧТО МОЖЕТ ОПРЕДЕЛЯТЬ ПРОСТРАНСТВЕННЫЕ РАЗЛИЧИЯ В УРОВНЕ СМЕРТНОСТИ?}

Современный этап устойчивого роста ожидаемой продолжительности жизни в России охватил не только центры регионов, но и их периферию. Однако темпы снижения уровня смертности в центрах и остальных населенных пунктах, как и величина разрыва в $e_{0}$ между ними на момент начала исследования, существенно различаются по субъектам Федерации. Как результат, пока в одних регионах рост ожидаемой продолжительности жизни сопровождался конвергенцией в уровне смертности между центром и остальной частью, в других преимущество центров только увеличивалось.

Различия в уровне смертности зависят как от условий на макроуровне, или «контекста» территории (иными словами, «эффекта среды»), так и от различий на микроуровне - в социально-демографических характеристиках конкретных жителей (Cummins et al. 2007). Если «эффект среды» оказывает влияние на все население какой-либо территории, то индивидуальные характеристики напрямую могут быть не связаны с местом проживания, однако неравномерность в их распределении между жителями различных территорий будет непременно оказывать влияние на агрегированные показатели смертности в них.

К важнейшим социально-демографическим характеристикам, влияющим на ожидаемую продолжительность жизни человека, относят уровень образования, уровень доходов, профессиональный статус, брачный статус, этническую принадлежность, религию и др. (Marmot, Shipley, Rose 1984; Valkonen 1992; Mackenbach et al. 2003; Von Gaudecker, Scholz 2007). Все они в той или иной степени определяют образ жизни и поведение индивида в отношении своего здоровья и подверженность факторам риска: курению, злоупотреблению алкоголем и наркотиками, неправильному питанию, низкой физической активности, гипертонии и др.

К средовым эффектам относят пространственные различия в социальноэкономических, политических и экологических условиях, в доступе к инфраструктуре, прежде всего к системе здравоохранения, в том числе неотложной медицинской помощи, в благоустройстве и качестве жилищного фонда (Diez-Roux 2002). Вместе с тем контекстуальный эффект, как правило, находит свое отражение во многих индивидуальных 
характеристиках. Так, уровень доходов домохозяйств выше там, где есть высоко оплачиваемые рабочие места; от уровня развития местной экономики зависят также образовательный и профессиональный состав населения, направление миграционных потоков.

Таким образом, более высокий уровень социально-экономического развития или другие привлекательные для миграции и проживания факторы (климат, развитая инфраструктура, в том числе досуговая, образовательная) формируют более «здоровое население» с более высокой продолжительностью жизни. И наоборот, в регионах с неблагоприятными социальными и экономическими условиями может возникнуть культура аномии, способствующая распространению нездорового образа жизни и высокому уровню смертности (Shaw, Dorling, Mitchell 2002).

\section{В РОССИИ МИГРАЦИОННЫЙ ПОТОК НАПРАВЛЕН ИЗ ПЕРИФЕРИИ РЕГИОНОВ В ИХ ЦЕНТРЫ}

Несмотря на депопуляцию, охватившую большую часть территории страны в 2000-2010-е гг., многие региональные столицы не только сохранили, но и нарастили численность населения. Как следствие, в 2003-2018 гг. доля населения, проживающего в региональных центрах, во всем населении неизменно увеличивалась (рисунок П1 Приложения). Отчасти это обусловлено более благоприятным соотношением чисел смертей и рождений в центрах вследствие более молодой возрастной структуры в них, однако главный источник роста таких городов - приток мигрантов как международных, так и внутренних. Более того, главными поставщиками внутренних мигрантов в региональные центры, как правило, являются прочие населенные пункты того же региона (Карачурина, Мкртчян 2016).

Миграционные потоки, направленные из периферии регионов в их центры, не только способствуют концентрации населения в ограниченном числе городов и «опустыниванию» периферии, но и приводят к «ухудшению» структуры населения с точки зрения уровня его здоровья на территориях, теряющих население в миграционном обмене с центрами. Согласно теории «здорового мигранта», миграция ассоциирована с позитивной селекцией по уровню здоровья, т. е. уровень смертности среди мигрантов ниже, чем среди принимающего населения, равно как и среди отдающего (Razum, Zeeb, Rohrmann 2000).

Таким образом, можно предположить, что динамика доли центра в населении региона будут напрямую связана с направлением и темпами изменения центрпериферийного разрыва в ео. Так, самый высокий прирост (свыше 7 процентных пунктов) доли центра в населении всего региона между 2003 и 2018 гг. отмечался в Тюменской, Кировской, Сахалинской областях, Якутии, Карелии, Бурятии, Красноярском крае субъектах Федерации, для которых характерен значительный центр-периферийный разрыв в $e_{0}$. В целом размер прироста доли центров в населении регионов между 2003 и 2018 гг. объясняет около 40\% дисперсии в величине разрыва в $e_{0}$ между центрами и прочими населенными пунктами в 2018 г. (рисунок П2 Приложения). 
Поскольку большинство вузов расположено в региональных центрах, учебная миграция (переезд выпускников школ и ссузов с целью получения высшего образования) является важной составляющей центр-периферийных потоков миграции в России. При этом учебная миграция вносит значительный вклад в увеличение качества человеческого капитала (доли людей с высшим образованием в населении) в центрах в ущерб периферии.

\section{ДОЛЯ НАСЕЛЕНИЯ С ВЫСШИМ ОБРАЗОВАНИЕМ В СТОЛИЦАХ РЕГИОНОВ РОССИИ В ДВА РАЗА ВЫШЕ, ЧЕМ ЗА ИХ ПРЕДЕЛАМИ}

В СССР, а затем и в России ожидаемая продолжительность жизни мужчин и женщин, имеющих высшее образование, существенно превышала соответствующие показатели для менее образованных групп населения (Пьянкова, Фаттахов 2017). Более того, дифференциация $e_{30}{ }^{7}$ в зависимости от уровня образования постоянно нарастала от оценок для 1979 г. к оценкам для 2015 г., главным образом за счет увеличения отрыва в ожидаемой продолжительности жизни населения с высшим образованием (Харькова, Никитина, Андреев 2017).

Люди с высшим образованием чаще практикуют самосохранительное поведение (в противовес рискованному), а также обладают более совершенными навыками социальной адаптации, особенно в кризисы (Щур 2019). Бремя смертности от травм и так называемых алкогольных причин смерти намного менее выражено среди россиян с высшим образованием (Shkolnikov et al. 2006). Проведенный нами анализ различий в уровне смертности между региональными центрами и прочими населенными пунктами показал, что в последних он выше в молодых и средних трудоспособных возрастах от внешних причин смерти и некоторых заболеваний, свидетельствующих о низкой социальной адаптации умерших.

Перепись 2010 г. показала, что во всех исследуемых субъектах Федерации доля населения с третичным уровнем образования была выше в региональном центре (Росстат 2012). Так, доля населения, имеющего высшее образование, в центрах, в среднем по 67 регионам, составляет 31,6\%, за пределами центров - 16,5\%, почти двукратное преимущество региональных столиц. Принимая во внимание наблюдаемую в России дифференциацию долголетия по образовательным группам, справедливо предположить, что разрыв в $e_{0}$ между центрами и периферией во многом объясняется различиями в образовательной структуре их населения.

\section{ОГРАНИЧЕНИЕ РАБОТЫ}

Хотя некоторые наблюдения, высказанные нами относительно причин наличия центрпериферийного разрыва в продолжительности жизни внутри регионов России, могут быть применимы и к анализу межрегиональных различий в величине и направлении изменений

\footnotetext{
${ }^{7}$ Ожидаемая продолжительность жизни в возрасте 30 лет (как правило, уровень образования человека редко меняется после 30 лет).
} 
центр-периферийного разрыва, наша работа не содержит подробного анализа социальноэкономических и/или физико-географических детерминант межрегионального разнообразия и пространственной картины выделенных нами различных типов регионов.

\section{ЗАКЛЮЧЕНИЕ}

В исследуемый период (2003-2018 гг.) в подавляющем большинстве регионов России ожидаемая продолжительность жизни при рождении в региональных центрах была выше, чем в прочих населенных пунктах. При этом, в 2003-2011 гг. отмечалась тенденция к росту преимущества центров, сменившаяся в 2012 г. тенденцией к конвергенции в уровне смертности. Впрочем, утверждать наверняка, что показатели ожидаемой продолжительности жизни в центрах и на периферии российских регионов сближаются, можно будет только после проведения следующей переписи населения. Хотя в 2011 г. и был изменен принцип учета миграции в России, приведший к значительному росту числа регистрируемых мигрантов, попадающих в поле зрения отечественной статистики, мы не можем полностью исключить вероятность того, что перепись 2021 г., как и перепись 2010 г., покажет завышение текущим учетом численности населения на «периферии» и его занижение в «центрах». В таком случае фактический разрыв в $e_{0}$ между региональными центрами и прочими населенными пунктами окажется выше расчетного.

Величина разрыва в $e_{0}$ между центром и остальной частью региона большей частью зависит от уровня смертности на периферии, в то время как направление изменения разрыва зависит от динамики $e_{0}$ как в центре, так и на периферии. В регионах, где разрыв в $e_{0}$ уменьшается, это происходит в первую очередь за счет догоняющих темпов снижения уровня смертности за пределами центра. Напротив, регионы, для которых характерна дивергенция в уровне смертности между центром и периферий, отличаются более высокими значениями и темпами роста $e_{0}$ в столицах. Кроме того, в IV-VI типах регионов, где центр-периферийный разрыв ниже, чем в среднем по стране, значения $e_{0}$ выше и, наоборот, в I-III типах они ниже среднероссийского, а разрыв - выше. При этом самый быстрый рост ожидаемой продолжительности жизни в 2003-2018 гг. на уровне всего региона (без разделения на центр и периферию) показали III и VI типы регионов, где отмечалась конвергенция в показателях смертности между центром и периферией.

Разрыв в $e_{0}$ для мужчин, а также изменение этого показателя со временем определяется главным образом разницей в уровне смертности в молодом и среднем (2554 года) возрасте. Дифференциация в уровне смертности женщин в данной возрастной группе между центрами и периферией также имеет значение, но несколько меньшее, чем для мужчин. Среди причин смерти, определяющих отставание периферии от центров в этой возрастной группе, в первую очередь выделяются внешние причин смерти, а также такие заболевания, как кардиомиопатия, туберкулез, цирроз и некоторые другие, говорящие о скорее маргинальном образе жизни умерших и об их выпадении из социума. Представляется, что вследствие более благоприятной образовательной структуры, а также селективного эффекта миграции доля «маргинального» населения в региональных центрах ниже, чем на периферии. Таким образом, различия в уровне смертности в молодом и среднем возрасте между центрами и прочими населенными пунктами можно объяснить 
различиями в социально-демографических характеристиках их жителей. В то время как более низкий уровень смертности старшего возраста от хронических заболеваний в центрах - следствие более развитой системы здравоохранения в них.

Если географические различия в уровне смертности вызваны, в первую очередь, социально-экономической дифференциацией пространства, можно ли добиться полной конвергенции лишь посредством мер, затрагивающих развитие системы здравоохранения, и/или других инициатив в области защиты общественного здоровья? Иными словами, возможно ли искоренение центр-периферийного разрыва в $e_{0}$ в России при сохранении пространственного неравенства в уровне социально-экономического развития? На примере Германии мы видим, как проведение эффективной политики общественного здравоохранения, направленной на сглаживание пространственных различий в уровне смертности, позволило свести к минимуму разрыв в уровне смертности между «старыми» и «новыми» федеральными землями даже при сохранении ощутимой гетерогенности социально-экономических условий (van Raalte et al. 2020).

\section{БЛАГОДАРНОСТИ}

Авторы выражают благодарность анонимным рецензентам, чьи комментарии, на наш взгляд, позволили существенно улучшить рукопись статьи.

\section{ЛИТЕРАТУРА}

Андреев Е.М. (1979). Продолжительность жизни в СССР: дифференциальный анализ. Е.М. Андреев, А.Г. Вишневский (Ред.), Продолжительность жизни: анализ и моделирование (с. 7-31). М.: Статистика.

Андреев Е.М. (1982) Метод компонент в анализе продолжительности жизни. Вестник статистики, 9, 42-47. URL: http://www.demoscope.ru/weekly/knigi/andreev/andreev.pdf

Андреев Е.М. (2012). О точности результатов российских переписей населения и степени доверия к разным источникам информации. Вопросы статистики, 11, 21-35. URL: http://www.demoscope.ru/weekly/2013/0549/analit01.php

Андреев Е.М., Кваша Е.А., Харькова Т.Л. (2006). Особые точки на карте смертности. Население России 2003-2004. В А.Г. Вишневский (Ред.), Одиннадияатый-двенадияатый ежегодный демографический доклад (сс. 298-305). М.: «Наука».

Вишневский А.Г., Щур А.Е. (2019). Смертность и продолжительность жизни в России за полвека. Оргздрав: новости, мнения, обучение, 5(2), 10-21. DOI: 10.24411/2411-86212019-12003.

Данилова И.А. (2015). Проблемы качества российской статистики причин смерти в старческом возрасте. Успехи геронтологии, 28(3), 409-414. URL: https://www.hse.ru/data/2018/10/11/1155689100/\%D0\%94\%D0\%B0\%D0\%BD\%D0\%B8\% D0\%BB\%D0\%BE\%D0\%B2\%D0\%B0.pdf

Захаров С.В. (Ред.) (2019). Население России 2017. Двадиать пятый ежегодный демографический доклад. М.: Издательский дом Высшей школы экономики. 
Иванова А., Семенова В., Дубровина Е. (2004). Что скрывается за "другими болезнями сердца"? Демоскоп Weekly, 181-182. URL:

http://www.demoscope.ru/weekly/2004/0181/tema02.php

Иванова А.Е. Михайлов А.Ю., Семенова В.Г. (2009). Потери продолжительности и качества жизни населения России. Народонаселение, 3, 40-49. URL: https://cyberleninka.ru/article/n/poteri-prodolzhitelnosti-i-kachestva-zhizni-naseleniya-rossii

Иванова А.Е., Сабгайда Т.П., Семенова В. Г., Запорожченко В. Г., Землянова Е.В., Никитина С.Ю. (2013). Факторы искажения структуры причин смерти трудоспособного населения России. Социальные аспекты здоровья населения, 32(4). URL: http://vestnik.mednet.ru/content/view/491/30

Карачурина Л.Б., Мкртчян Н.В. (2016). Региональные центры России в фокусе миграции Вопросы географии, т. 141. В В. Котляков, В. Н. Стрелецкий и др. (Ред.), Проблемьл регионального развития России. М.: Издательский дом «Кодекс», 209-233.

Лексин В.Н. (2009). Города власти: административные центры России. Мир России: Социология, этнология, 18(1), 3-33. URL: https://mirros.hse.ru/article/view/5127

Мкртчян Н.В. (2012). Проблемы учета населения отдельных возрастных групп в ходе переписи населения 2010 г.: причины отклонений полученных данных от ожидаемых. М.Б. Денисенко (Ред.), Демографические аспектьл социально-экономического развития (сс. 197-214). Москва: МАКС Пресс.

Нефедова Т.Г., Трейвиш А.И. (2020). Поляризация и сжатие освоенных пространств в центре России: тренды, проблемы, возможные решения. Демографическое обозрение, 7(2), 31-53. DOI: 10.17323/demreview.v7i2.11138.

Новосельский С.А. (1911). О различиях в смертности сельского и городского населения Европейской России. Общественный врач, 4, 40-62.

Новосельский С.А. (1916). Смертность и продолжительность жизни в России. СанктПетербург: Типография MBД. URL:

http://www.demoscope.ru/weekly/knigi/novoselskij/novoselskij_1916.pdf

Папанова Е.К., Школьников В.М., Тимонин С.А. (2019). Особенности динамики и компоненты снижения смертности в Москве в 1989-2017 гг. Демографическое обозрение, 6(1), 50-103. DOI: 10.17323/demreview.v6i1.9113.

Пьянкова А.И., Фаттахов Т.А. (2017). Смертность по уровню образования в России. Экономический журнал ВШЭ, 21(4), 623-647. URL:

https://ej.hse.ru/data/2017/12/28/1160683586/\%D0\%9F\%D1\%8C\%D1\%8F\%D0\%BD\%D0 $\%$ BA\%D0\%BE\%D0\%B2\%D0\%B0.pdf

Росстат (2012). Всероссийская перепись населения 2010. URL:

https://www.gks.ru/free_doc/new_site/perepis2010/croc/perepis_itogi1612.htm

Российская экономическая школа (2019). Российская база данных по рождаемости и смертности. URL: http://demogr.nes.ru/index.php/ru/demogr_indicat/data (данные загружены 15.03.2020).

Харькова Т.Л., Никитина С.Ю., Андреев Е.М. (2017). Зависимость продолжительности жизни от уровня образования в России. Вопросы статистики, 8, 61-68. URL: https://voprstat.elpub.ru/jour/article/view/546

Школьников В.М. (1987). Географические факторы продолжительности жизни. Известия АН СССР. Серия Географическая, 3(12), 35-44. 
Щур А.Е. (2019). Уровень образования как фактор демографического прогноза. Демографическое обозрение, 6(2), 204-208. DOI: 10.17323/demreview.v6i2.9878.

Cummins S., Curtis S., Diez-Roux A.V., Macintyre S. (2007). Understanding and representing 'place' in health research: A relational approach. Social Science \& Medicine, 65(9), 18251838. DOI: 10.1016/j.socscimed.2007.05.036.

Diez-Roux A.V. (2002). A glossary for multilevel analysis. Journal of Epidemiology and Community Health, 56(8), 588-594. DOI: 10.1136/jech.56.8.588.

Mackenbach J.P., Bos V., Andersen O., Cardano M., Costa G., Harding S., Reid A., Hemström Ö., Valkonen T., Kunst A.E. (2003). Widening socioeconomic inequalities in mortality in six Western European countries. International Journal of Epidemiology, 32(5), 830-837. DOI: 10.1093/ije/dyg209.

Marmot M. (2005). Social determinants of health inequalities. Lancet, 365(9464), 1099-1104. DOI: $10.1016 / \mathrm{s} 0140-6736(05) 74234-3$.

Marmot M.G., Shipley M.J., Rose G. (1984). Inequalities in death-specific explanations of a general pattern? Lancet, 1(8384), 1003-1006. DOI: 10.1016/s0140-6736(84)92337-7.

Razum O., Zeeb H., Rohrmann S. (2000). The 'healthy migrant effect' - not merely a fallacy of inaccurate denominator figures. International Journal of Epidemiology, 29(1), 191-192. DOI: $10.1093 / \mathrm{ije} / 29.1 .191$.

Sen A. (1998). Mortality as an Indicator of Economic Success and Failure. The Economic Journal, 108(446), 1-25. DOI: 10.1111/1468-0297.00270.

Shaw M., Dorling D., Mitchell R. (2002). Health, Place and Society. Singapore: Pearson.

Shkolnikov V.M., Andreev E., Jasilionis D., Leinsalu M., Antonova O., McKee M. (2006). The changing relation between education and life expectancy in Central and Eastern Europe in the 1990s. Journal of Epidemiology and Community Health, 60(10), 875-881. DOI: 10.1136/jech.2005.044719.

Timonin S., Danilova I., Andreev E., Shkolnikov V.M. (2017). Recent mortality trend reversal in Russia: are regions following the same tempo? European Journal of Population, 33(1), 733 763. DOI: 10.1007/s10680-017-9451-3.

Timonin S., Jasilionis D., Shkolnikov V., Andreev E.M. (2020). New perspective on geographical mortality divide in Russia: a district- level cross- sectional analysis, 2008-2012. Journal of Epidemiology and Community Health, 74(2), 144-150. DOI: 10.1136/jech-2019213239.

Valkonen T. (1992). Trends in regional and socio-economic mortality differentials in Finland. International Journal of Health Sciences, 3(3-4), 157-166. URL: https://pubmed.ncbi.nlm.nih.gov/12345858/

van Raalte A.A., Klüsener S., Oksuzyan A., Grigoriev P. (2020). Declining regional disparities in mortality in the context of persisting large inequalities in economic conditions: the case of Germany. International Journal of Epidemiology, 49(2), 486-496. DOI: 10.1093/ije/dyz265

Vasin S., Costello C.A. (1997). Spatial, age, and cause-of-death patterns of mortality in Russia, 1988-1989. In J.L. Bobadilla, C.A. Costello, F. Mitcell (eds.), Premature Death in the New Independent States (66-119). Washington, DC: National Academies Press.

Von Gaudecker H., Scholz R. (2007). Differential mortality by lifetime earnings in Germany. Demographic Research, 17, 83-108. DOI: 10.4054/demres.2007.17.4 


\section{ПРИЛОЖЕНИЕ}

Таблица. Типы регионов (I-VI) в зависимости от величины разрыва в ео и динамики его изменения в 2003-2018 гг.

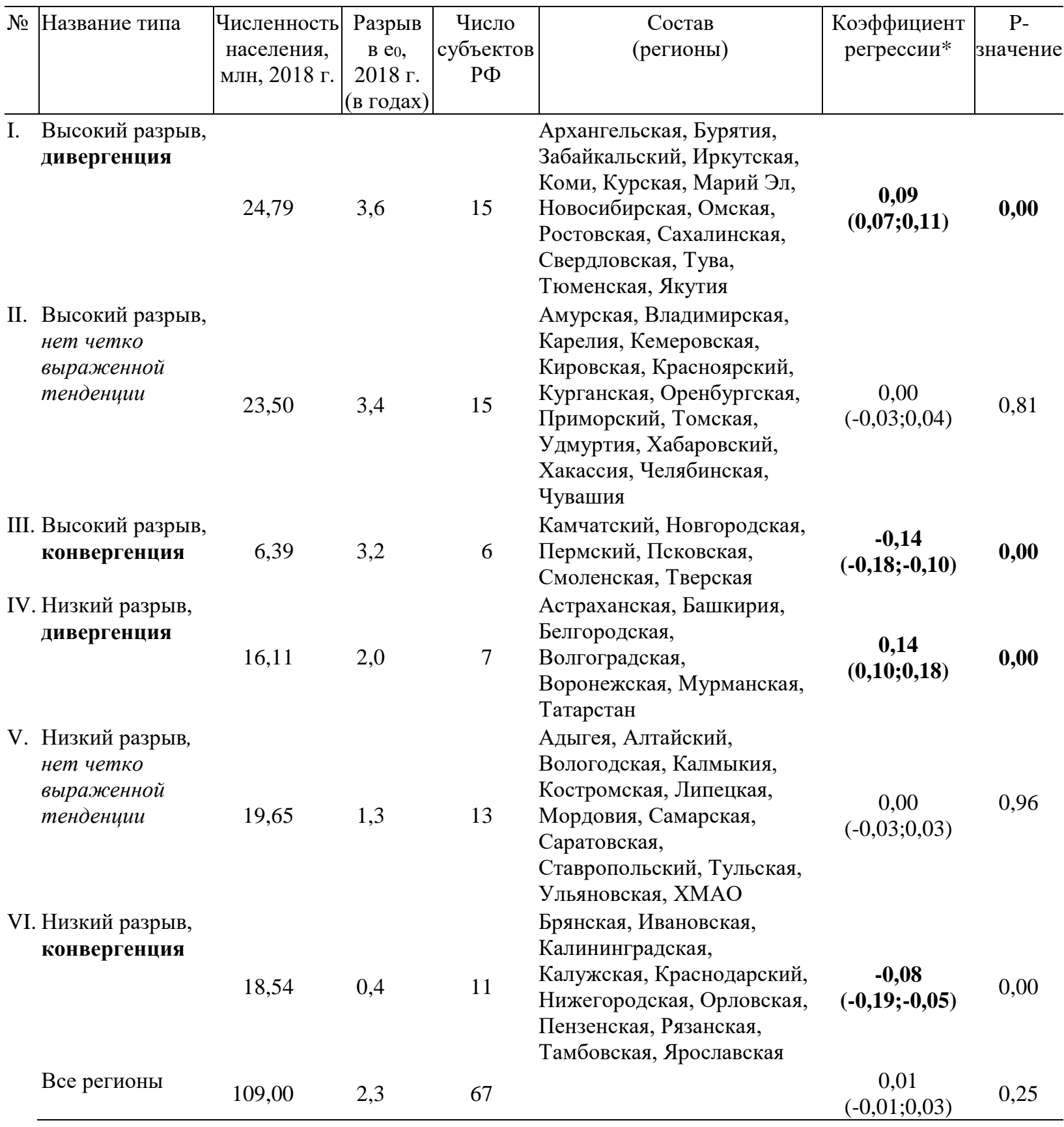

* - В круглых скобках указан 95\%-ный доверительный интервал; жирным шрифтом выделены статистически значимые коэффициенты. 


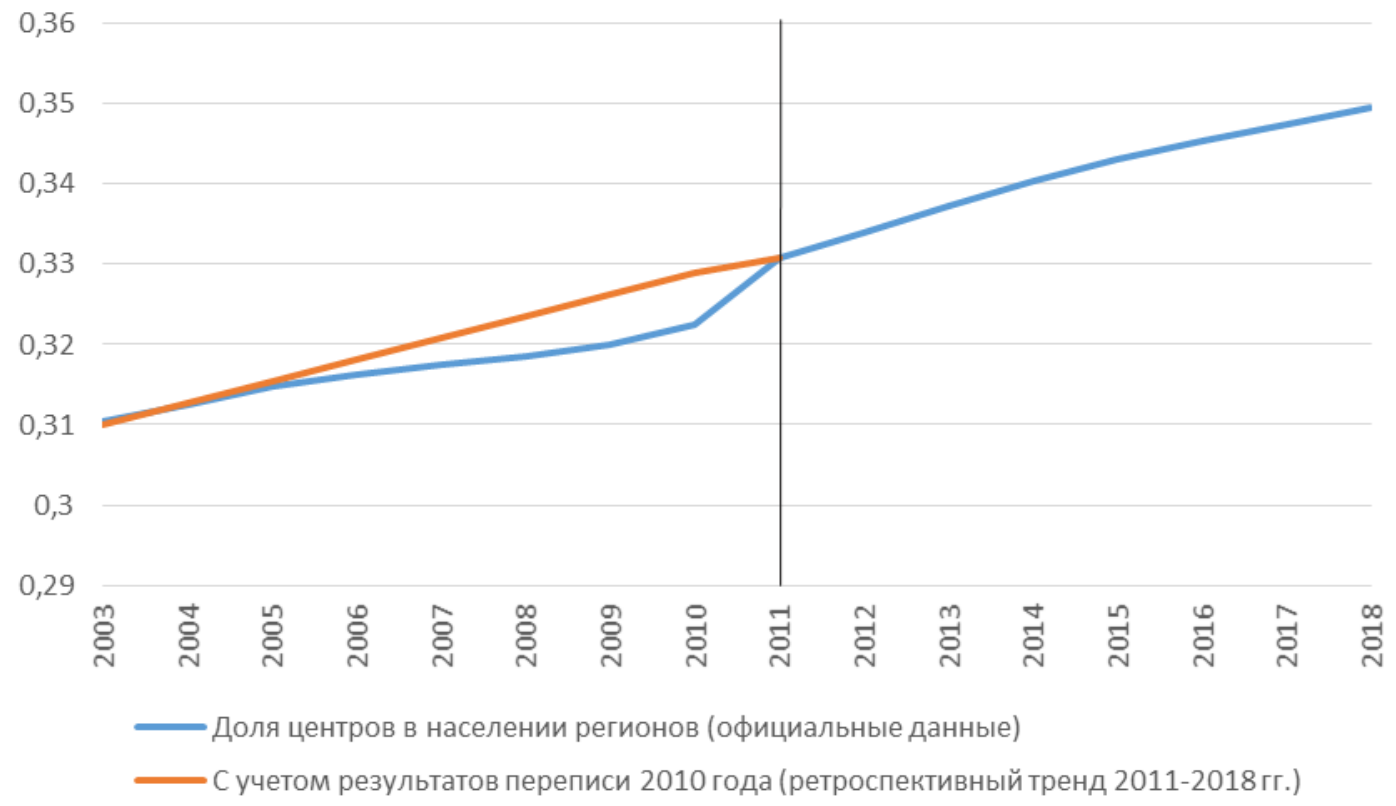

Рисунок П1. Доля населения в российских регионах, проживающего в региональном центре, \%, 2003-2018

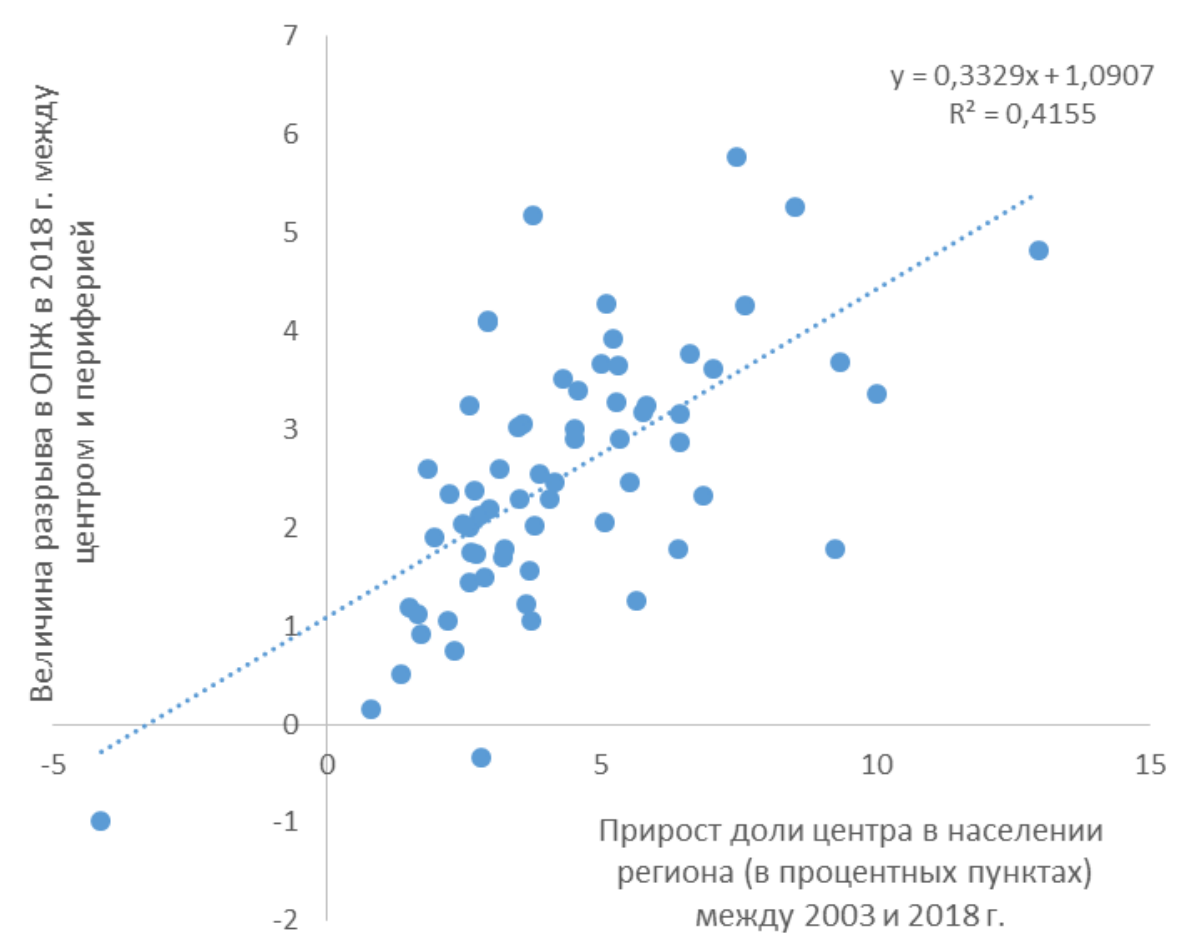

Рисунок П2. Влияние прироста доли центра в населении региона между 2003 и 2018 г. на величину разрыва в ео в 2018 г. между центром и прочими населенными пунктами 


\title{
CENTER-PERIPHERAL DIFFERENCES IN LIFE EXPECTANCY IN RUSSIA: REGIONAL ANALYSIS ALEKSEI SHCHUR, SERGEY TIMONIN
}

\begin{abstract}
Elevated mortality (compared to the West) and significant spatial differences in life expectancy are serious challenges facing Russia. Improving Russians' health and increasing life expectancy by reducing inequality in mortality between regions and settlements are closely intertwined with the goals of spatial development of Russia, aimed at reducing interregional differences in the quality of life.

This paper presents an assessment of the scope and dynamics of changes in mortality differences between the 'center' and the 'periphery' in 67 regions of Russia, which are home to three-quarters of the country's population. The selected research period - 2003-2018 - is characterized by a steady increase in life expectancy at birth (LE) in Russia. Using unpublished data from Rosstat for cities, we estimated life expectancy at birth in 67 regional centers and in the rest of the regions ('periphery'). Depending on the magnitude of the differences in LE and the dynamics, we identified 6 types of regions. For the regions with the gap in LE between the center and the periphery larger than on average, the decomposition method was applied, which made it possible to determine the key age groups and causes of death responsible for such high differences.

In 36 regions of Russia classified as types I-III, the center-peripheral gap exceeded the average Russian level, while only in six regions in 2003-18 there was a tendency to reduce the size of this gap. The decomposition results showed that elevated mortality of males in the periphery is due to a higher mortality rate at working age from external causes of death, especially from traffic accidents, homicides and suicides, as well as from 'alcoholic' causes of death; females in the periphery suffer from higher mortality rate at older ages from chronic non-communicable diseases.

Despite the seemingly 'objective' nature of the mortality differences between the center and the periphery (the advantage of the former is due to the socio-demographic characteristics of its residents, the educational structure of the population, as well as selective migration), the positive experience of other countries shows that effective public health policies can significantly reduce the range of spatial inequality in mortality rates even if significant heterogeneity in the level of social-economic development of the territories persists.
\end{abstract}

Key words: life expectancy, mortality, Russian regions, regional capitals, center and periphery.

\footnotetext{
Aleksei ShChur (aschur@hse.ru), National ReSEarch University Higher School of Economics, Russia.

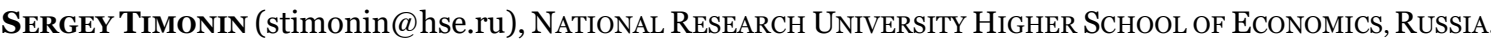

THIS ARTICLE IS THE PRODUCT OF A RESEARCH PROJECT IMPLEMENTED AS PART OF THE BASIC RESEARCH PROGRAMME AT THE NATIONAL RESEARCH UNIVERSITY HIGHER SCHOOL OF ECONOMICS (HSE).
}

DATE RECEIVED : AUGUST 2020.

\section{REFERENCES}

Andreev E.M. (1979). Length of life in the USSR: A differential analysis. In E. Andreev, A. Vishnevski (Eds.), Length of life: Analysis and modelling. Moscow: Statistika. (In Russ).

Andreev E.M. (1982). The method of components in the analysis of length of life. Vestnik Statistiki, 9, 42-47. URL: http://www.demoscope.ru/weekly/knigi/andreev/andreev.pdf (In Russ).

Andreev E.M. (2012). On accuracy of Russia population censuses results and level of confidence in different sources of information. Statistical Issues, 11, 21-35. URL: http://www.demoscope.ru/weekly/2013/0549/analit01.php (In Russ). 
Andreev E.M., Kvasha E.A., Khar'kova T.L. (2006). Special points on the mortality map. In A.G. Vishnevsky (Ed.), Naselenie Rossii 2003-2004. Odinnadtsatyy-dvenadtsatyy ezhegodnyy demograficheskiy doklad (pp. 298-305) [Russia's Population in 2003-2004. 11-12 Annual Demographic Report]. Moscow: Nauka. (In Russ).

Center for Demographic Research. (2018). Russian Fertility and Mortality Database. Retrieved from http://www.demogr.nes.ru/index.php/ru/demogr_indicat/data (data downloaded on 15.03.2020).

Cummins S., Curtis S., Diez-Roux A.V., Macintyre S. (2007). Understanding and representing 'place' in health research: A relational approach. Social Science \& Medicine, 65(9), 1825-1838. DOI: 10.1016/j.socscimed.2007.05.036.

Danilova I. (2015). Problems of the quality of cause-specific mortality statistics at advanced ages. Advances in Gerontology, 3, 409-414. URL: https://www.hse.ru/data/2018/10/11/1155689100/\%D0\%94\%D0\%B0\%D0\%BD\%D0\%B $8 \% \mathrm{D} 0 \% \mathrm{BB} \% \mathrm{D} 0 \% \mathrm{BE} \% \mathrm{D} 0 \% \mathrm{~B} 2 \% \mathrm{D} 0 \% \mathrm{~B} 0 . p d f$ (In Russ).

Diez Roux A.V. (2002). A glossary for multilevel analysis. Journal of Epidemiology and Community Health, 56(8), 588-594. DOI: 10.1136/jech.56.8.588.

Federal State Statistics Service (Rosstat) (FSSS). (2012). All-Russian population census 2010. URL: https://www.gks.ru/free_doc/new_site/perepis2010/croc/perepis_itogi1612.htm (In Russ).

Ivanova A., Semenova V., Dubrovina E. (2004). Chto skryvayetsya za "drugimi boleznyami serdtsa"? [What is hidden behind 'other heart diseases'?]. Demoskop Weekly, 181-182. URL: http://www.demoscope.ru/weekly/2004/0181/tema02.php (In Russ).

Ivanova A.E. Mikhaylov A.YU., Semenova V.G. (2009). Poteri prodolzhitel'nosti i kachestva zhizni naseleniya Rossii [Loss of length and quality of life of Russian population]. Narodonaseleniye, 3, 40-49. URL: https://cyberleninka.ru/article/n/poteriprodolzhitelnosti-i-kachestva-zhizni-naseleniya-rossii (In Russ).

Ivanova A.E., Sabgayda T.P., Semenova V.G., Zaporozhenko V.G., Zemlyanova E.V., Nikitina S.YU. (2013). Factors distorting structure of death causes in working population in Russia. Social aspects of population health, 4(32). URL: http://vestnik.mednet.ru/content/view/491/30/ (In Russ).

Karachurina L.B., Mkrtchyan N.V. (2016). Regional'nyye tsentry Rossii v fokuse migratsii [Regional centers of Russia in migration's focus]. In V. Kotlyakov, V.N. Streletskiy, O.B. Glezer, S.G. Safronov (Eds.), Problemy regional'nogo razvitiya Rossii (pp. 209-233). Moscow: Izdatel'skiy dom «Kodeks». (In Russ).

Khar'kova T.L., Nikitina S.YU., Andreev E.M. (2017). Dependence of life expectancy on the education levels in Russia. Statistical Issues, 8, 61-68. URL: https://voprstat.elpub.ru/jour/article/view/546 (In Russ).

Leksin V.N. (2009). Goroda vlasti: administrativnyye tsentry Rossii [Cities of Power: Administrative Centres of Russia]. Mir Rossii: Sotsiologiya, etnologiya, 18(1), 3-33. URL: https://mirros.hse.ru/article/view/5127 (In Russ).

Mackenbach J.P., Bos V., Andersen O., Cardano M., Costa G., Harding S., Reid A., Hemström Ö., Valkonen T., Kunst A.E. (2003). Widening socioeconomic inequalities in mortality in six Western European countries. International Journal of Epidemiology, 32(5), 830-837. DOI: $10.1093 / \mathrm{ije} / \mathrm{dyg} 209$.

Marmot M. (2006). Social determinants of health inequalities. Lancet, 365(9464), 1099-1104. DOI: 10.1016/s0140-6736(05)74234-3.

Marmot M.G., Shipley M.J., Rose G. (1984). Inequalities in death-specific explanations of a general pattern? Lancet, 1(8384), 1003-1006. DOI: 10.1016/s0140-6736(84)92337-7.

Mkrtchyan N.V. (2012). Issues of acquiring population in certain age groups during the Census of 2010: The reasons for the deviations from the expected counts. In M. B. Denisenko 
(Ed.), Demographic aspects of socio-economic development (pp. 197-214). Moscow: MAKS Press (In Russ).

Nefyodova T., Treyvish A. (2020). Polarization and shrinkage of active space in the core of Russia: trends, problems and possible solutions. Demographic Review, 7(2), 31-53. https://doi.org/10.17323/demreview.v7i2.11138 (In Russ).

Novosel'skij S.A. (1911). O razlichiyah v smertnosti sel'skogo i gorodskogo naseleniya Evropejskoj Rossii [Differences in mortality between the rural and urban population of European Russia]. Obshchestvennyj vrach, 4. (In Russ).

Novosel'skij S.A. (1916). Smertnost' i prodolzhitel'nost' zhizni v Rossii [Mortality and life expectancy in Russia]. Saint Petersburg: Tipografiya MVD. URL: http://www.demoscope.ru/weekly/knigi/novoselskij/novoselskij_1916.pdf (In Russ).

Papanova E., Shkolnikov V., Timonin S. (2019). Distinctive features and components of mortality decrease in Moscow in 1989-2017. Demographic Review, 6(1), 50-103. https://doi.org/10.17323/demreview.v6i1.9113 (In Russ).

Pyankova A.I., Fattakhov T.A. (2017). Smertnost' po urovnyu obrazovaniya v Rossii [Mortality by level of education in Russia] // HSE economic journal. 21(4), 623-647. URL: https://ej.hse.ru/data/2017/12/28/1160683586/\%D0\%9F\%D1\%8C\%D1\%8F\%D0\%BD\% D0\%BA\%D0\%BE\%D0\%B2\%D0\%B0.pdf (In Russ).

Razum O., Zeeb H., Rohrmann S. (2000). The 'healthy migrant effect'- not merely a fallacy of inaccurate denominator figures. International Journal of Epidemiology, 29(1), 191-192. DOI: 10.1093/ije/29.1.191.

Sen A. (1998). Mortality as an Indicator of Economic Success and Failure. The Economic Journal, 108(446), 1-25. DOI: 10.1111/1468-0297.00270.

Shaw M., Dorling D., Mitchell R. (2002). Health, Place and Society. Singapore: Pearson.

Shchur A. (2019). Education level as a factor in demographic forecasting. Demographic Review, 6(2), 204-208. https://doi.org/10.17323/demreview.v6i2.9878 (In Russ).

Shkolnikov V.M. (1987). Geographical factors of length of life. Izvestiya AN SSSR. Geographical Series, 3(12), 35-44. (In Russ).

Shkolnikov V.M., Andreev E., Jasilionis D., Leinsalu M., Antonova O., McKee M. (2006). The changing relation between education and life expectancy in central and eastern Europe in the 1990s. Journal of Epidemiology and Community Health, 60(10), 875-881. DOI: 10.1136/jech.2005.044719.

Timonin S., Danilova I., Andreev E., Shkolnikov V.M. (2017). Recent mortality trend reversal in Russia: are regions following the same tempo? European Journal of Population, 33(1), 733- 763. DOI: 10.1007/s10680-017-9451-3.

Timonin S., Jasilionis D., Shkolnikov V., Andreev E.M. (2020). New perspective on geographical mortality divide in Russia: a district- level cross- sectional analysis, 20082012. Journal of Epidemiology and Community Health, 74(2), 144-150. DOI: 10.1136/jech-2019-213239.

Valkonen T. (1992). Trends in regional and socio-economic mortality differentials in Finland. International Journal of Health Sciences, 3(3-4), 157-166. URL: https://pubmed.ncbi.nlm.nih.gov/12345858/

van Raalte A.A., Klüsener S., Oksuzyan A., Grigoriev P. (2020). Declining regional disparities in mortality in the context of persisting large inequalities in economic conditions: the case of Germany. International Journal of Epidemiology, 49(2), 486-496. DOI: 10.1093/ije/dyz265

Vasin, S., Costello C.A. (1997). Spatial, age, and cause-of-death patterns of mortality in Russia, 1988-1989. In J.L. Bobadilla, C.A. Costello, F. Mitcell (Eds.), Premature Death in the New Independent States (pp. 66-119). Washington, DC: National Academies Press. 
Vishnevsky A.G., Shchur A.E. (2019). Smertnost' i prodolzhitel'nost' zhizni v Rossii za polveka [Mortality and life expectancy in Russia for half a century]. Orgzdrav: novosti, mneniya, obucheniye, 5(2), 10-21. DOI: 10.24411/2411-8621-2019-12003. (In Russ).

Von Gaudecker H., Scholz, R. (2007). Differential mortality by lifetime earnings in Germany. Demographic Research, 17, 83-108. DOI: 10.4054/demres.2007.17.4

Zakharov S.V. (2019). Naseleniye Rossii 2017: dvadtsat' pyatyy ezhegodnyy demograficheskiy doklad [Russia's population: 25 annual demographic report]. Moscow: Izdatel'skiy dom NIU VSHE. (In Russ). 